\title{
The Library's Role in College Instruction
}

Dr. Wilson, for many years librarian of the University of North Carolina and subsequently dean of the Graduate Library School at the University of Chicago, read the following paper before the College and Reference Section of the North Carolina Library Association at Charlotte on Oct. 20, 1943 .

$\mathrm{F}^{\text {OR LIBRarians whose special field of }}$ $\Gamma_{\text {activity is }}$ the facilitation of the use and understanding of print World War II has provided a shocking revelation. In the period when Congress was debating whether to draft pre-Pearl Harbor fathers, it showed that 750,000 men of draft age had been rejected by the armed forces because they could not read and write. It showed that thousands of others could not qualify for training in special programs and that thousands of men who had had college training could not be commissioned as officers because they had not learned how to receive or transmit orders with full understanding and clarity.

The shock experienced by librarians was not due to the novelty of the revelation but to the numbers involved. They had long suspected that the high percentage of failures by students in college subjects had been due to limited vocabularies, low reading rate, and belowaverage reading comprehension. They had long been convinced that in certain states and regions these limitations of reading ability were closely related to short school terms, poor libraries, and lack of instruction in effective methods of reading and study.-They had not known how extensive such limitations were nor had they previously thought how serious the results of such limitations could be in a national crisis or in a period when a postwar program of world reorganization and readjustment must be thought out and carried into effect by the total population.

The purpose of this paper grows out of this situation and is threefold. The paper is intended ( $I$ ) to center attention upon the fact that college students served by the libraries represented at this conference are less well equipped as readers than students in other regions; (2) to describe some of the measures which have been employed to improve instruction through library use; and (3) to suggest additional methods by which college study can be improved through library use.

What are the facts concerning the reading abilities of entering students in North Carolina colleges? When I first became librarian at the University of North Carolina in I9OI I soon discovered that frequently as high as 40 per cent of the freshman class failed one or more of their examinations at the end of their first term of study. Without the benefit of statistical or reading studies I came to the 
conclusion that one of the contributing causes was the inability of many students to read with sufficient speed to cover the subjects assigned or to understand clearly what they were supposed to learn through reading. A key word in a sentence not understood meant for them failure to comprehend the paragraph or page in which the word appeared.

Today the matter is largely removed from the area of speculation or opinion. Through state-wide and nationwide vocabulary tests and tests to determine the rate of reading and comprehension, the fact is well established that students in certain states and regions consistently rank above the nationwide average and that others rank below. The per cent of men of draft age rejected in World War I on account of reading limitations was particularly high in the South. The situation in World War II has been similar. In 1942 , when the reading of sixth-grade pupils in North Carolina schools was checked against the national average, it was found to be definitely below the national average. ${ }^{1}$ Of the seven hundred freshmen entering the university in 1942 , it was shown through vocabulary and reading tests that two hundred of the number were in need of remedial training for the removal of specific reading deficiencies. Nonresident students entering the university from Northern and Midwestern states have consistently ranked higher on vocabulary and reading tests than resident students.

Efforts to improve instruction through library use have been made by: (I) agencies other than colleges and libraries, (2) colleges, and (3) libraries, and have taken a number of forms.

\footnotetext{
1 Gordon, Mary Agnes, and Durost, Walter N. "The Sixth-Grade Testing Program." North Carolina
} Education, v. 9, no. 3, 1942 .

\section{Outside Agencies}

Of the agencies other than colleges and libraries which have affected college library use, the Carnegie Corporation has played a notable role. ${ }^{2}$ Through grants totaling \$I,609,000 to 235 liberal arts, junior, teachers, and Negro colleges between I929 and 194I, it has aided in building up book collections for the support of instruction in specific subjects and has sharply focused the attention of college presidents, deans, curriculum committees, and librarians upon the role of the library in college education. 'It has also given special collections of materials in art and music to a number of colleges, and through the various advisory committees which administered the grants has published the Shaw ${ }^{3}$ and Mohrhardt ${ }^{4}$ lists and numerous articles which have dealt with the organization, administration, and use of materials in teaching.

The General Education Board has attacked the problem in a different manner. In 1936 it undertook, through a special seminar for college librarians held at the Graduate Library School of the University of Chicago, to provide instruction in methods of integrating instruction and library use for librarians of eighteen Southern colleges and universities to which it was making grants for various purposes. Since that date it has helped finance a number of college workshops in which college library programs have been included; it has given individual Southern college librarians scholarships and fellow-

\footnotetext{
${ }^{2}$ Wilson, Louis R. "The Use of the Library in Instruction." In John Dale Russell, ed. New Fron. tiers in College Instruction. Chicago, University of tiers in College Instr

3 Shaw, Charles B. A List of Books for College Libraries. Chicago, American Library Association, I 931 .

Shaw, Charles B. A List of Books for College Li. braries 1931-1938. Supplement. Chicago, American Library Association, 1940.

4 Mohrhardt, Foster E. $A$ List of Books for Junior College Libraries. Chicago, American Library Association, 1937.
} 
ships for further study to fit themselves for more effective participation in the college program; and it has aided a group of colleges in making a self-survey of their instructional procedures, including library use. In the summers of $194 \mathrm{I}$ and 1942 it contributed to the support of special conferences of Southern colleges and universities which emphasized the relation of the library to teaching and research. ${ }^{5}$

Accrediting associations have likewise attempted to insure greater use of the library in the attainment of college educational objectives. The North Central and Southern Associations of Colleges and Secondary Schools have steadily raised their standards for library service and have sought to increase the efficiency of the library as an integral part of the college educational process. The Association of American Colleges has sought the same end through two additional means. In I940 it published Teaching with Books by Branscomb, ${ }^{6}$ the emphasis of which was placed squarely upon the greater use of library materials, and during the present year it has scheduled a librarian on its arts program to spend three days at those colleges which request such service in conferring with administrative officers, library committees, members of the faculty, library staff, and student body concerning matters relating to the enrichment of instruction through improved library service.

The efforts described so far have originated outside the college. Those which have been made within the college have been primarily concerned with the curricu-

\footnotetext{
Southern Association of Colleges and Secondary Schools. "General Report on the Work Conference on Higher Education." The Southern Association $Q$ uarterly, v. 5, no. 4, I941; v. 6, no. 4, I942.

6 Branscomb, Harvie. Teaching with Books; $A$ Study of College Libraries. Chicago, Association of American Colleges and American Library Association,
r940.
}

lum. The adoption of a new type of curriculum inevitably produces a corresponding change in the character of library use. Three types of curriculum which have markedly affected library use may now be noted.

\section{The Junior College}

The first is the curriculum of the junior college, which grows out of the interests and needs of the individual student and is implemented largely by individual guidance and counseling. In such situations the library becomes one of the principal means for the integration of instruction. The library program of Menlo Junior School and College, ${ }^{7}$ developed in 1936 after a self-survey of its library service, may be used to illustrate the effect of this type of curriculum. A reading council was appointed; space in the library for chairs, tables, open shelves, and facilities for displaying library materials was more than trebled; instruction in improving silent reading was instituted; students were encouraged to keep daily reading records; and reading records and the results of reading tests were made available to faculty counselors. The book collections were approximately doubled in four years; a divisional collection for the social sciences and classroom and dormitory libraries were set up; musical recordings and reproductions of pictures were provided; and a college-wide stimulation of desirable reading was inaugurated. Through a reading council, the combined library instructional efforts of the institution were coordinated and an evaluation of the program in terms of the attainment of objectives was undertaken.

Adams, Harlen Martin. The Junior College Library Program. Chicago, American Library Association and Stanford University Press, I940. 
The second curricular change that has greatly increased library use has grown out of the interest of colleges in general education. This interest has manifested itself through the survey or orientation course in junior colleges and the lower divisions of four-year colleges. The nature of such courses requires little comment. Their library implications, however, call for consideration. At the University of Chicago their library implications were fully considered before they were put into effect. ${ }^{8} \mathrm{~A}$ special library was provided to house the materials selected to support them. An extensive syllabus including required and optional readings was developed for each of them. Reading materials were selected to cover all the objectives of the courses. Recency of publication was strongly emphasized. Duplication of titles was stressed and an extensive rental library service was also provided to supplement this service.

This was only one part of the program. The syllabi have been frequently revised. New titles have been regularly added. Faculty counselors are available for consultation about any phase of the student's work, including his use of library materials. Discussion groups supplement general class meetings and assistance is given concerning methods of study and library use. The use of the card catalog, encyclopedias, periodical indexes, and the principal reference materials of the main library is taught as an integral part of an English course required of all freshmen, and, in the event students seem unable to keep up with their reading assignments, they are sent to a reading clinic for testing and training in speed of reading and reading comprehension. Specially prepared

\footnotetext{
${ }^{8}$ Boucher, Chauncey Samuel, and Brumbaugh, A J. The Chicago College Plan. Chicago, University of Chicago Press, 1940.
}

motion pictures are also provided to supplement lectures, reading, and discussion.

\section{Florida Plan}

The University of Florida follows a different plan from that of Chicago in its effort to improve student study and reading. ${ }^{9}$ Entering students are given extensive tests to discover physical defects, poor reading habits, confused or fuzzy thinking, meager vocabulary, and limited experience which may affect their study and understanding adversely. On the basis of the results of the tests, remedial programs are planned. Then, for ten weeks, a reading and discussion program is prescribed in which extension of vocabulary, increase in reading rate and comprehension, and greater skill in selecting the central idea, in summarizing passages, in making outlines, in locating materials, and in performing all those exercises which aid one in mastering the ability to comprehend the written word, are emphasized. The program has been based upon a special collection of one thousand volumes, and attention to reading, writing, and speech difficulties is provided, through a reading, writing, and speech laboratory and the university library. A cumulative reading record is kept by each student and is made the basis of discussion and practice in writing. Of six thousand freshmen who had taken the course between 1935 and I94I, 74 per cent showed increased reading comprehension and the entire group increased its average rate of reading from 306 words per minute to 397 , an increase of 30 per cent.

At North Carolina State College instruction in English composition ${ }^{10}$ has been

\footnotetext{
${ }^{\circ}$ Wise, J. Hooper. "The Improvement of Reading Habits" and "Writing Laboratory in English Courses." In John Dale Russell, ed., op. cit.

10 Clark, Joseph D. "A Four-Year'Study of Freshman English." English Journal, v. 24, no. 5, I935.
} 
based for several years upon an intensified reading program as contrasted with drill based upon a textbook. The results of tests recorded over a period of years, in which the two methods were compared, demonstrated the superiority of the reading method over the use of the textbook.

Junior colleges and the lower division of four-year colleges have been able to carry out such programs because of their freedom to break with tradition and of their willingness to apply the results of experimentation and research to college teaching. Upper divisions of colleges and universities have been less aggressive in experimentation with curricula than the lower divisions. Where such experimentation and modification have occurred they have expressed themselves through honors courses, tutorial or preceptorial programs, house plans, and other means.

Library use forms the principal basis of instruction in honors courses. The student, usually a superior student in the junior or senior class, undertakes under faculty guidance a program of independent reading and study based on a long-range goal of achievement. The library usually extends special privileges to such students and facilitates his work in every way possible. In the case of tutorial and preceptorial programs, the student is usually expected to consult with his faculty adviser concerning his emotional and social growth as well as his intellectual development. The impact of this type of program upon the library has been carefully recorded at Southwestern College at Memphis, where the total number of books loaned for overnight and home use increased in a six-year period from 46.02 books per student to 78.86 per year. ${ }^{11}$

Other modifications of the curriculum

11 Branscomb, op. cit., p. 66. have effected corresponding modifications in the use of library materials in instruction. Through house plans, Harvard has placed libraries of from five thousand to twelve thousand volumes in each of seven resident halls to support supervised study under tutors as well as to provide recreational reading. Through reading periods, during which classes are suspended, the University of Chicago has provided an opportunity for extensive reading, writing, and consultation with instructors. Through "great books" courses, St. Johns has centered attention largely upon a hundred or more of the classics around which it has developed its instructional program. All of these devices involve the library in varying degrees and have as their object the development of the student in directing his own study and thinking.

\section{Changes in Libraries}

Changes within the library which have promoted its use in instruction may now be mentioned. Of first importance is the attempt members of many library staffs have made to understand the educational program of the college as it relates to the library and to participate intelligently in carrying it into effect. Eight hundred or more college and university librarians have taken advanced degrees either in subject fields or library science during the past decade. Many of them have taken graduate work in special subjects and have pursued courses dealing with the college curriculum, the administration of higher institutions, and methods of educational counseling, to increase their proficiency as library counselors or advisers of students.

The second change which librarians have helped to effect has involved the physical reorganization of library 
materials for specific uses and the modification of library buildings or the arrangement of new buildings to secure conditions which are conducive to effective study. The new library building at Davidson College has been developed on the open-shelf principle. The library at Wellesley has provided a new series of alcoves in its main reading room to give greater quiet and intimacy of contact with books. The new library building at the University of Colorado has been built on a divisional basis, with special reading rooms for the humanities and social-sciences, the effect of which upon instruction has been reported to be very pronounced. Proposed plans for a new library at Stephens College call for a building which will house under one roof the general library, divisional and classroom libraries, classrooms, conference rooms, and faculty studies.

Librarians have, in the third instance, taken an active part in the study of college student reading. Theses and articles written by them have constituted one of the principal sources of information available concerning various aspects of college student reading. The findings of these studies would make valuable reading for college executives and deans of instruction and should be placed in their hands as often as opportunity permits.

\section{Libraries on Teaching Level}

In the fourth instance, some college libraries have undertaken to place their administration on a teaching rather than on a stripped-down, administrative, or library-housekeeping level. They have recognized the teaching function of the library and have organized the staff and procedures of the library on that basis. In doing this they have kept three groups in mind: ( $I$ ) the student at the college or lower division level, (2) the advanced student, and (3) the faculty member. In illustrating what I mean by such organization I shall draw extensively upon the program of the library of the Woman's College of the University of North Carolina described by Librarian Guy R. Lyle in a recent letter. The library of that institution is motivated by the desire to cooperate with the teaching faculty in educating students for their life work and for development of the right kind of intellectual and social attitudes. The very fact that the staff has such a point of view and a real feeling of being engaged with the faculty in a common intellectual enterprise is perhaps the library's greatest contribution to instruction. The library rates highly the efficiency of its professional and clerical staff in the acquisition, processing, and distribution of books, but it never loses sight of the fact that its most profitable work is done at the desks in helping students to find information on subjects they are interested in or in connection with class work. It frequently happens that this "instructional phase" of the library's work extends beyond the desk and it is essentially the same kind of service.

Such a philosophy of college librarianship has to be implemented to make it effective. The librarian has outlined the procedures followed by his staff. During orientation week the library conducts tours. This is a cooperative undertaking of one of the library staff members, the faculty chairman of the freshman class, and upperclass students. The library provides instruction in the use of the library through a member of the reference staff who has the title of Instructor in Library Use. Her primary function is to aid in 
such instruction. Such instruction is not given in a formal course but is planned in connection with term papers and other definite problems to make it as effective as possible. The majority of new students are usually reached through the English classes, but instruction is neither confined to these students nor to new students. An advanced class in classics or in home economics may need help in using special library tools of use to them. An effort is made to reach them by working through the instructors. It is impossible to evaluate the results of the work although it is known that it is helpful and appreciated. The important thing is to know the instructors and to show them some of the actual materials the library staff feels their students should know about. Personal visits and written statements are used in making contacts with instructors and a special handbook ${ }^{12}$ has been prepared for their use. Instruction is given in lectures, through inspection trips, and by means of slides and a student library handbook.

The loan and reference desks serve as indicators of the quality of instruction and the success of teaching. As deficiencies are revealed, an effort is made to correct them. If too many books are placed on reserve or the reserve program is not working properly, the faculty is notified. If students tend to do their reserve reading in spurts a large-scale graph of such reading is made which is shown to instructors and students for the information and guidance of both groups. Loan periods for reserves are flexible: one-day, three-day, and oneweek charging periods meet student requirements better than one type of period.

Emphasis is placed by the library upon

${ }^{12}$ Library of the Woman's College of the University of North Carolina. Using the Library: a Faculty Handbook. Greensboro, Woman's College of the University of North Carolina, 1943. the selection of books and upon the instructional function of the readers' adviser. The advisory service has a fourfold aim: (I) to develop the habit of good reading, (2) to provide books for recreational reading and to encourage an appreciation of the book arts, (3) to assist students, especially those with poor literary background, in choosing suitable titles from reading lists assigned to class study, and (4) to encourage students to develop their own personal libraries.

The program is further implemented by the usual reference and research services for advanced students, graduates, and faculty members; a picture collection has been established to which all slides owned formerly by the departments are being added and indexed; library exhibits are coordinated with instruction through the assistance of the faculty; and an extensive series of publications is issued, including the two handbooks mentioned above, a monthly list of new books, and special publications such as "Popular Science"13 and The Woman's Collection: A Bibliugraphy. ${ }^{14}$

The third purpose of this papernamely, to suggest methods by which college study can be further improved through library use-has already been achieved in part by means of the examples of library participation in instructional activities in some colleges. Such participation is not universal, however. There are other measures which may be taken which should receive consideration. I shall emphasize four.

First of all, the administration of the

${ }^{13}$ Library of the Woman's College of the University of North Carolina. "Popular Science Book List." Library Journal 67:404-I I, May II 1942

14 Library of the Woman's College of the University of North Carolina. The Woman's Collection: $a$ Bibliography of Material in All Matters Pertaining to Women's Interests. Greensboro, Woman's Collexe of the University of North Carolina, 1941. 
college should be urged to provide funds for maintaining the library at a teaching rather than at a library-housekeeping level. The library staff should be used as a part of the teaching staff and the library must be equipped and supported as a teaching department. Its procedures are different from those of the classroom and the laboratory, but its objectives are the same. Classroom, laboratory, and library alike are useful only insofar as they contribute to the student's social, intellectual, and spiritual development. The library contributes to the learning process as definitely as either of the other two. If it does not, then it fails in performing its proper function.

In the second place, the library staff should become more expert in participating in the detection and removal of the vocabulary and reading deficiencies of students and should work more extensively with the faculty in promoting student interest and efficiency in reading. The library's function is to promote the effective use of graphic materials. If a student does not understand the meaning of such symbols, if he cannot read rapidly and understandingly, he cannot profit fully from the special means of education for which the library has been established and is maintained to provide. The accumulation of reading records of students and observations upon the difficulties which students experience in carrying out their reading assignments, would undoubtedly contribute to increased student effectiveness.
Third, the library should seek the opportunity to participate more extensively in the guidance program of students. Opportunities provided through orientation week, through meeting students at the loan desk and in the reference room, and through contacts with various student groups, might well lead to library participation in the vocational and educational guidance program of the college. The library can display books dealing with these fields. It should also be able, through its readers' advisory service, to counsel students as well.

Fourth, whether the library actually assumes the role of teaching in the ways indicated, it can at least feature in its display cases and upon its open shelves the kinds of books which aid students in learning how to take notes, how to study, how to prepare bibliographies, and how to utilize library materials in mastering a subject and in acquiring ability to write about it clearly and interestingly. Such books should be made available so that every student may have the best possible guidance in learning how to secure and organize the kinds of information he requires and how to synthesize it for use in college and after-college life. To aid the student in extending his vocabulary and reading rate, to assist him in taking the fuzziness out of his thinking, to stimulate him in reading those works which inspire men to high living and thinking-these are chief among the shining goals of college librarianship. 